\title{
MINIMUM VALUE APPROACH FOR MODELLING OF THE BUCKLING RESISTANCE OF WELDED I-SECTION HIGH STRENGTH STEEL COLUMNS
}

\author{
M. D. GAJEWSKI ${ }^{1}$, M. A. GIŻEJOWSKI ${ }^{2}$, R. B. SZCZERBA ${ }^{3}$
}

\begin{abstract}
The paper deals with determination of flexural resistance buckling curves for welded I-section steel members made of high strength steel (S 690). In the paper the previously proposed BF analytical model is used for approximation of FEM results obtained using moderately large deformation shell theory and ABAQUS/Standard software. Final formulation of flexural resistance buckling curves is possible through the use of the MerchantRankine-Murzewski approach adopted extensively in the authors' previous papers. For nonlinear optimization, which is needed for analytical model parameters determination, the Wolfram Mathematica package is used. Obtained results for S 690 steel are presented against the results for S 355 steel.
\end{abstract}

Keywords: buckling curve, welded I-sections, high strength steel, FEM modelling

\section{INTRODUCTION}

In this paper, the approach for buckling resistance curves prediction in case of high strength steel (S 690) welded I-section columns is presented. The paper is a continuation of the work presented in $[3,10]$, where the same formulation, based on the approach called there as the Merchant-RankineMurzewski approach (M-R-M approach), was used for common steel grades (below S 460). Current design specifications of EN 1993-1-1 [7] postulate that for the rolled sections of the steel grade

\footnotetext{
${ }^{1}$ DSc., PhD., Eng., Warsaw University of Technology, Faculty of Civil Engineering, Al. Armii Ludowej 16, 00-637 Warsaw, Poland, e-mail: m.gajewski@il.pw.edu.pl

${ }^{2}$ Prof., DSc., PhD., Eng., Warsaw University of Technology, Faculty of Civil Engineering, Al. Armii Ludowej 16, 00-637 Warsaw, Poland, e-mail: m.gizejowski@il.pw.edu.pl

${ }^{3}$ MSc. Eng., Doctoral Study, Warsaw University of Technology, Faculty of Civil Engineering, Al. Armii Ludowej 16, 00-637 Warsaw, Poland, e-mail: r.szczerba@il.pw.edu.pl
} 
S 460, the degrading effect of residual stresses on the reduction buckling resistance factor of steel compression members is less pronounced that for the common steel grades. Table 1 present the upgrading of the buckling curves by one or two with regard to the steel grade $\mathrm{S} 460$ in comparison in reference to the grades below S 460. The codification with regard to welded sections does not foresee any upgrading of buckling curves, and EN 1993-1-1 [7] requires for buckling about z-z axis, regardless of the steel grade, to use the curve $c$ for the I-section girders with the flange thickness less or equal to $40 \mathrm{~mm}$ and the curve $d$ otherwise. The purpose of this paper is to present the buckling curve formulation for columns of high steel grade S 690, based on the FEM simulations presented elsewhere [10], and compare the results with those presented in [3] for the common steel grade S 355. To predict the influence of welding residual stresses on the buckling resistance curves, the material and geometrical imperfections were included separately.

Table 1. Buckling curve classification according to EN 1993-1-1 [7]

\begin{tabular}{|c|c|c|c|c|c|}
\hline Section type & \multicolumn{2}{|c|}{ Section geometry $\left[t_{f}\right.$ in $\left.\mathrm{mm}\right]$} & Buckling about axis & Grade less than S 460 & Grade S 460 \\
\hline \multirow{8}{*}{$\begin{array}{l}\text { Rolled I and } \mathrm{H} \\
\text { sections }\end{array}$} & \multirow{4}{*}{$\frac{h}{b}>1.2$} & \multirow{2}{*}{$t_{f} \leq 40$} & $y-y$ & $a$ & $a_{0}$ \\
\hline & & & $z-z$ & $b$ & $a_{0}$ \\
\hline & & \multirow{2}{*}{$40<t_{f} \leq 100$} & $y-y$ & $b$ & $a$ \\
\hline & & & $z-z$ & $c$ & $a$ \\
\hline & \multirow{4}{*}{$\frac{h}{b} \leq 1.2$} & \multirow{2}{*}{$t_{f} \leq 100$} & $y-y$ & $b$ & $a$ \\
\hline & & & $z-z$ & $c$ & $a$ \\
\hline & & \multirow[t]{2}{*}{$t_{f}>100$} & $y-y$ & $d$ & $c$ \\
\hline & & & $z-z$ & $d$ & $c$ \\
\hline
\end{tabular}

\section{FEM SIMULATIONS OF THE BUCKLING RESISTANCE OF HIGH STEEL}

\section{STRENGTH COLUMNS}

The assumptions for FEM analysis conducted in this paper are the same as used in the papers [3] and [8]. The only difference is the fact that now the high strength steel S 690 is being analysed, what influences the plasticity limit, being one of the parameters of steel constitutive model. Steel is modelled as an isotropic elastic-plastic material. In case of the isotropic elasticity the Young modulus is equal to $210 \mathrm{GPa}$ while Poisson ratio is equal to 0.3 . For plasticity the Maxwell-HuberMises-Hencky yield condition is assumed and associated with this condition plastic flow law. The plasticity limit for steel S 690 was assumed as equal to $690 \mathrm{MPa}$. After yielding the isotropic strain hardening is assumed with plastic modulus E/1000. All boundary value problems are solved using 
ABAQUS/Standard FEM software with the constitutive modelling explained above [1,2]. The only difference is that these constitutive relationships are implemented in frame of moderately large deformation theory, where strain tensors are treated as logarithms from stretch tensors (resulting from polar decomposition of gradient of deformation tensor), cf. [1,2]. In the analysed problems of stability of welded I-section columns they were modelled using shell elements with linear shape functions. The residual stresses caused by welding are modelled through an initial self-balanced stress field. In Fig. 1b a residual stress pattern for chosen I-section is given, whereas dimensions and geometrical data are presented in Fig. 1a. The residual stress pattern is represented by a piecewise linear function with different values of residual stresses in the tension and compression zones. Since the transition zone between the uniform residual stresses is rather small for welded sections, it is justified to adopt an approximate pattern consisting of rectangular residual stress blocks in tension and compression, without the transition zone. It yields $y_{1}=y_{2}$ and $z_{1}=z_{2}$ with different maximum stress ordinates in tension and compression. For common steel grades, the postwelding tensile residual stress $\sigma_{\text {res, ten }}=\psi_{\text {ten }} f_{y}$ reaches the steel strength (thus $\psi_{\text {ten }}=1$ ). Such an approximation of the residual stress pattern has been considered in [3] and maintained also hereafter.

a)

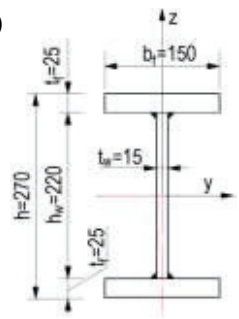

b)

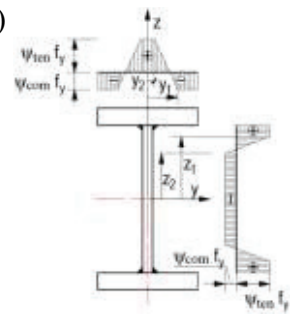

Fig. 1. Cross section chosen for analysis, a) geometrical dimensions, b) standard residual stress pattern [3]

The residual stress parameter $\psi_{t e n}$ in tension zone is kept constant for different heat transfer history. As a consequence, only the compression zone residual stress parameter $\psi_{\text {com }}$ is further considered as a variable. Discrete values from the range between 0.1 and 0.5 (the most unfavourable case for typical welded I-sections) are considered hereafter with an interval of 0.1 . Using the above assumptions, the FEM simulations had been performed and the results were presented in [3] for the steel grade S 355. Here the results for high steel strength grade S 690 obtained with the same assumptions are shown. It is concluded that it is highly questionable to use the buckling curves formulated for the beam-columns of common steel grades also for the high steel strength. The 
formulation presented hereafter is made for the steel grade S 690 and compared with that developed in the authors' earlier studies.

\section{MODEL FORMULATION FOR BUCKLING CURVE ESTIMATION}

\subsection{BUCKLING CURVE ESTIMATION BASED ON BF MODEL}

In the paper [3], the three different analytical formulations (SE model - strain free column with equilibrated residual stresses approach, SC model - strain compatibility approach and BF modelbest fit model were used for approximation of numerical results. For more details, the reference is to be made to $[3,10]$. In this paper, only BF model is applied as the one proved to be the most accurate in paper [3]. The basis for considered model was a trilinear constitutive relationship of $\sigma_{\text {eff }} \varepsilon_{e f f}$ for the post-welded steel (see Fig. 2 for the elastic- plastic steel relationship without hardening).

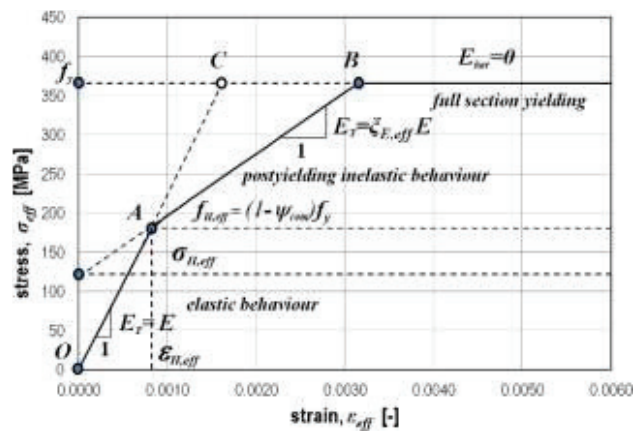

Fig. 2. Idealization of I-section effective properties in the form of welding-equivalent stress-strain diagram

The influence of welding is visible on that graph as a line $\mathrm{AB}$ inclined with smaller angle to the $\varepsilon_{\text {eff }}$ axis than initial stiffness represented by OA. The $\sigma_{\text {eff }} \varepsilon_{\text {eff }}$ relationship parameters $E_{T}$ and $\sigma_{H, \text { eff }}$ of the best fit model (BF model) are represented by their dimensionless equivalents $\xi_{E \text {,eff }}=E_{T} / E$ and $\xi_{H, \text { eff }}=$ $\sigma_{H, e f f} / f_{y}$ calibrated by the least square optimization with use of Mathematica function Non-Linear Model Fit. Using the notation presented in Fig. 2, this relationship may be expressed through the following formula:

$$
\sigma_{e f f}\left(\varepsilon_{e f f}\right)=\min \left(E \varepsilon_{e f f}, \sigma_{H, e f f}+E_{T} \varepsilon_{e f f}\right) \leq f_{y}
$$


On the basis of Fig. 2, the second relationship inside minimum bracket may be expressed as

$$
\sigma_{H, e f f}=\left(1-\frac{E_{T}}{E}\right) f_{H, e f f}=\left(1-\xi_{E, e f f}\right)\left(1-\psi_{c o m}\right) f_{y}
$$

Using the results of [3] and taking into account equation (2), the flexural buckling resistance curve affected by residual stresses may be written in the following form (substituting $\psi_{\text {eff }}=\psi_{\text {com }}$ ):

$$
\chi_{z, \text { res }}=\left(1-\psi_{\text {eff }}\right)\left(1-\xi_{E, e f f}\right)+\frac{\xi_{E, e f f}}{\bar{\lambda}_{z}^{2}}
$$

Expression (3.3) is valid when for a given $\bar{\lambda}_{z}, \chi_{z, \text { res }}<\min \left(1, \bar{\lambda}_{z}^{-2}\right)$. The calibration of parameters $\xi_{E, \text { eff }}$ and $\psi_{\text {eff }}$ was done in two ways. In the first variant (V1), a two stage calibration procedure was applied in which the calibration of $\xi_{E, \text { eff }}=E_{T} / E$ is firstly performed using the numerical results of $\chi_{z, \text { res }}$ and the fixed values of $\psi_{\text {eff }}=\psi_{\text {com }}$, and secondly - the calibration of $\psi_{\text {eff }}$ parameters using the

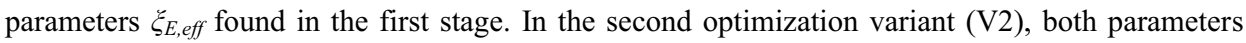
$\left(\xi_{E, \text { eff }}\right.$ and $\left.\psi_{e f f}\right)$ were determined at once. Analogous results obtained for S 355 steel may be found in $[3,10]$.

Table 2. Parameters describing the equivalent $\sigma-\varepsilon$ BF model for S 690 obtained in two step optimization procedure, respectively for variants $\mathrm{V} 1$ and $\mathrm{V} 2$

\begin{tabular}{|c|c|c|c|c|c|c|c|c|c|c|}
\hline Param. & \multicolumn{9}{|c|}{ V1 } & \multicolumn{5}{c|}{ V2 } \\
\hline$\psi_{\text {com }}$ & 0.1 & 0.2 & 0.3 & 0.4 & 0.5 & 0.1 & 0.2 & 0.3 & 0.4 & 0.5 \\
\hline$\xi_{E, \text { eff }}$ & 0.0045 & 0.0033 & 0.023 & 0.048 & 0.084 & 0.016 & 0.013 & 0.046 & 0.084 & 0.13 \\
\hline$\psi_{\text {eff }}$ & 0.10 & 0.20 & 0.31 & 0.42 & 0.52 & 0.12 & 0.21 & 0.34 & 0.46 & 0.58 \\
\hline
\end{tabular}

\subsection{MINIMUM VALUE BUCKLING CURVE FORMULATION BASED ON BF MODEL}

The reference is made to the authors' paper [3] in which the M-R-M buckling curve formulation with two variables $N_{c r}$ and $N_{c r, e f f}$ based on the BF model parameters has been presented. For columns with postwelding residual stresses $\left(0<\psi_{\text {com }} \leq 0.5\right)$ : 


$$
N_{b, \text { nom }}=\min \left(N_{c r}, N_{c r, e f f}\right) \leq N_{p l}
$$

The following notation is used: $N_{c r}$ - Euler elastic critical force, $N_{c r, e f f}=\sigma_{H, \text { eff }} A+\xi_{E, \text { eff }} N_{c r}$ - critical load with residual stresses taken into account, $N_{p l}=A f_{y}$ - yield axial force (where $\sigma_{H, \text { eff }}, \xi_{E, \text { eff }}$ as given in Fig. 2). Using the conventional dimensionless coordinates presented in Eurocode $3[6,7]$, the following minimum value version of equation (3.4) may be obtained:

$$
\chi_{z}=\min \left[\bar{\lambda}_{z}^{-2},\left(1-\xi_{E}\right)(1-\psi)+\xi_{E} \bar{\lambda}_{z}^{-2}\right] \leq 1
$$

where for $\psi_{c o m}=0: \xi_{E}=0$ and $\psi=0$, and for $\psi_{c o m}>0: \xi_{E}=\xi_{E, \text { eff }}$ and $\psi=\psi_{\text {eff. After randomization, the }}$ minimum value approach leads therefore to a two dimensional Weibull minima distribution of the buckling resistance [7]. As a result, the following equation is obtained for the reduction factor $\chi_{z}$ of an imperfect column $[4,9,11]$ subjected to residual stresses and initial bow deformations:

$$
\left(\chi_{z}\right)^{-n}=\bar{\lambda}_{z}^{2 n}+\left[\left(1-\xi_{E}\right)(1-\psi)+\xi_{E} \bar{\lambda}_{z}^{-2}\right]^{-n}
$$

in which $n$ is the imperfection factor to be best fitted to results of FEM simulations. The best fit imperfection factors $n$ are calibrated using again the Mathematica function Non-Linear Model Fit for five nonzero values of $\psi_{\text {com }}$ (see Table 2), and two extreme values of the geometric amplitude $e_{0}$, namely $L / 10000$ (quasi straight column) and $L / 750$ (the amplitude at the manufacturing tolerance level). The results for variants V1 and V2 of optimization are presented in Table 3, respectively in two mega-columns referred to $e_{0}$.

Table 3. Parameter n obtained for S 690 grade using two V1 and V2 variants for $e_{0}=\mathrm{L} / 10000$ and $e_{0}=\mathrm{L} / 750$

\begin{tabular}{|c|c|c|c|c|c|c|c|c|c|c|c|c|}
\hline Opt. & \multicolumn{9}{|c|}{$e_{0}=\mathrm{L} / 10000}$. & \multicolumn{6}{c|}{$e_{0}=\mathrm{L} / 750$} \\
\hline Var. & $\psi_{\text {com }}$ & $\psi_{\text {com }}$ & $\psi_{\text {com }}$ & $\psi_{\text {com }}$ & $\psi_{\text {com }}$ & Avg. & $\psi_{\text {com }}$ & $\psi_{\text {com }}$ & $\psi_{\text {com }}$ & $\psi_{\text {com }}$ & $\psi_{\text {com }}$ & Avg. \\
& 0.1 & 0.2 & 0.3 & 0.4 & 0.5 & $n$ & 0.1 & 0.2 & 0.3 & 0.4 & 0.5 & $n$ \\
\hline V1 & 7.33 & 6.37 & 5.94 & 6.17 & 5.74 & 6.06 & 1.66 & 1.90 & 1.87 & 1.88 & 1.88 & 1.84 \\
\hline V2 & 7.33 & 6.91 & 7.77 & 10.08 & 811.76 & 168.77 & 1.66 & 1.92 & 1.95 & 1.96 & 2.05 & 1.91 \\
\hline
\end{tabular}

Analysing the values of determined $n$ parameters it is clear that the optimization variant V1 leads to better results (in terms of variance and optimization stability). Let's take then for the following 
considerations the average value of $n$ from the V1 optimization variant $\left(n_{\text {avg }}=6.0\right.$ in case of $e_{0}=L / 10000$ and $n_{\text {avg }}=1.8$ in case of $e_{0}=L / 750$ ). In case of steel S 355 similar average $n$ parameter was determined as equal to $\left(n_{\text {avg }}=6.0\right.$ in case of $e_{0}=L / 10000$ and $n_{\text {avg }}=1.6$ in case of $\left.e_{0}=L / 750\right)$. Taking into account the fact that it would be more convenient to use for practical application the same $n$ parameters for both steel grades, let's assume $n=1.6$ in case of $e_{0}=L / 750$ for S 690 steel. The following graphs, solid lines represent analytical predictions, whereas discrete points show FEM results. Fig. 3 present how small is the difference in prediction accuracy taking $n=1.6$ instead of 1.8 in case of $e_{0}=L / 750$. Analysing the optimization parameters $n$ presented in the Table 3 one can conclude that for a geometric imperfection magnitude factor equal to $L / 10000$ the power coefficient is equal to 6.0. Than we have:

$$
\chi_{z}=\left\{\left(\bar{\lambda}_{z}^{2}\right)^{n}+\left[\left(1-\xi_{E}\right)(1-\psi)+\xi_{E} \bar{\lambda}_{z}^{-2}\right]^{-n}\right\}^{-(1 / n)} \leq 1, \quad \text { where } n=1.6 \text { or } n=6.0
$$

in which for $\psi_{c o m}>0$ the parameters $\xi_{E}=\xi_{E, \text { eff }}$ and $\psi=\psi_{\text {eff }}$ have to be taken from Table 2. However, one must bear in mind the fact that by assuming the same parameter $n=1.6$ for steel grades $\mathrm{S} 355$ and S 690 there is a slight decrease of the buckling resistance curves in case of high strength steel S 690 .
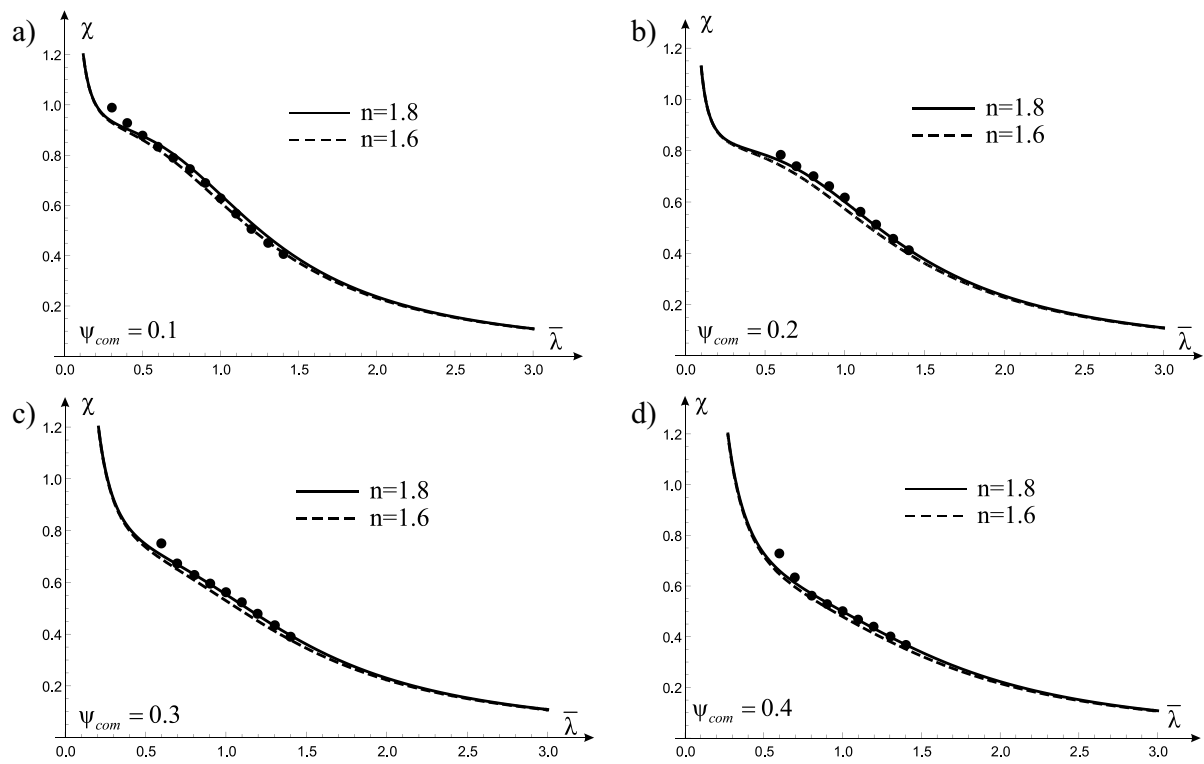


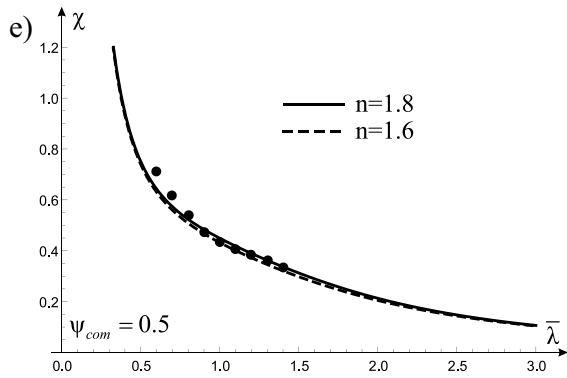

Fig. 3. Reduction factors $\chi_{z}$ calculated analytically and from FEM simulations for steel grade S 690, a) $\psi_{\text {com }}=0.1$, b) $\psi_{\text {com }}=0.2$, c) $\psi_{\text {com }}=0.3$, d) $\psi_{\text {com }}=0.4$, e) $\psi_{\text {com }}=0.5$ in case of $e_{0}=\mathrm{L} / 750$ and two different $n$ values

\section{COMPARISON OF MODEL PREDICTIONS FOR STEELS S 355 AND S 690}

Analytical models for S 355 and S 690 steel grades create an opportunity for detailed comparison of the flexural minor axis resistance curves of welded I-section members. In the Fig. $4 \mathrm{a}$ and Fig. $4 \mathrm{~b}$ (regarding respectively S 355 and S 690 steel grade) the outcomes of analytical models are compared with those from the use of FEM calculations. All results were gathered on one graph to show the whole spectrum of analysed cases. The imperfection magnitude $e_{0}=\mathrm{L} / 10000$ as upper resistance estimation (marked with empty circles) as well as the value of $e_{0}=\mathrm{L} / 750$ as lower resistance estimation (marked with solid circles) were taken into account. Outcomes for five nonzero values of $\psi_{\text {com }}$ were also presented.
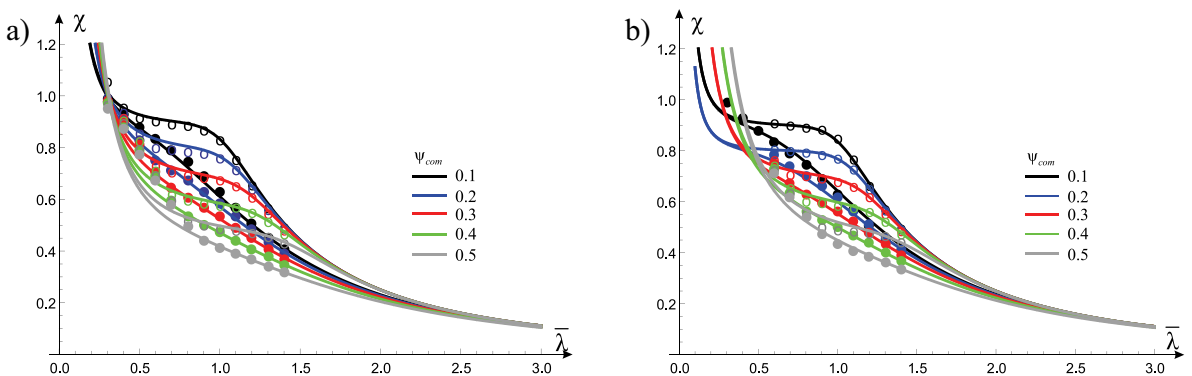

Fig. 4. Reduction factors $\chi_{z}$ for welded I-section members depending on $\psi_{\text {com }}$ for: a) S 355 and b) S 690 grade 
a)

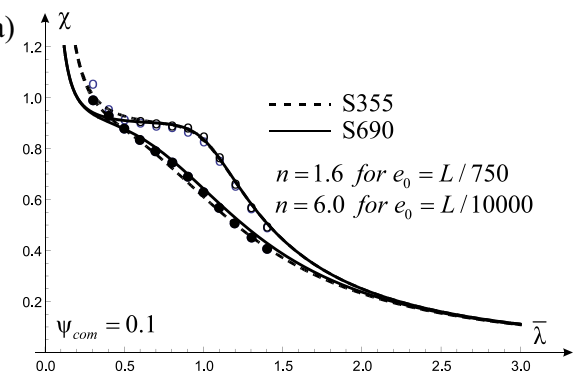

c)

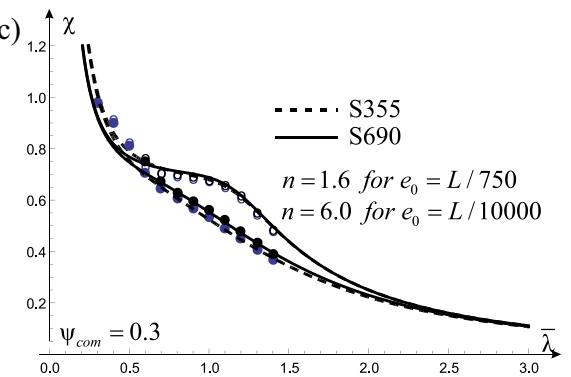

e)

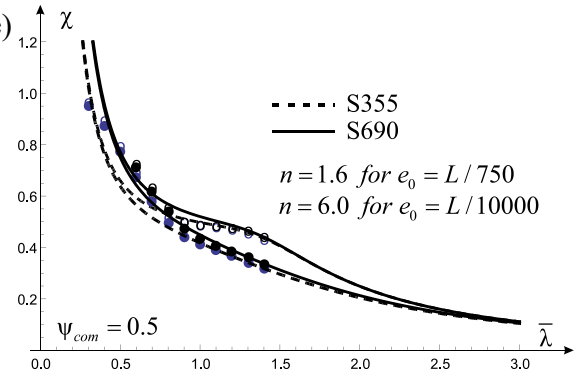

b) ${ }_{1.2} \uparrow$

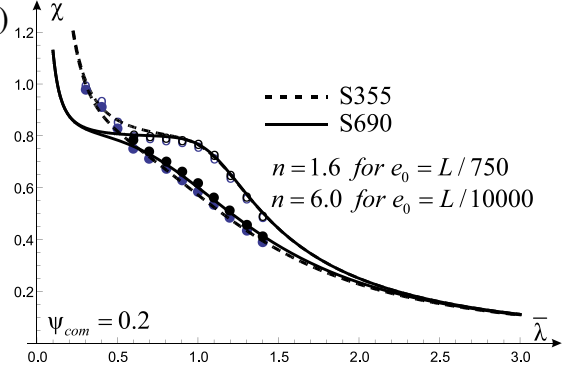

d)

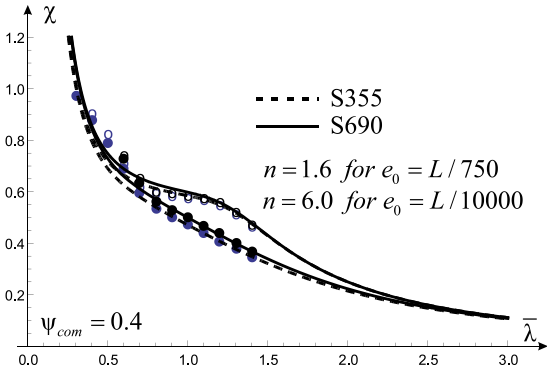

Fig. 5. Analytically predicted reduction factors $\chi_{z}$ against FEM simulation results for steel grades $\mathrm{S} 355$ and S 690, a) $\psi_{\mathrm{com}}=0.1$, b) $\psi_{\mathrm{com}}=0.2$, c) $\psi_{\mathrm{com}}=0.3$, d) $\psi_{\mathrm{com}}=0.4$, e) $\psi_{\mathrm{com}}=0.5$

In Fig. 5, the comparison of results for steel grades S 355 and S 690 is presented. Analytical outcomes with the application of parameters $n=1.6$ for $e_{0}=\mathrm{L} / 750$ and $n=6.0$ for $e_{0}=\mathrm{L} / 10000$ are confronted with those resulting from FEM calculations (the same $n$ parameters were used for both steel grades). Blue solid lines and discrete points represent steel grade S 355, whereas black colour corresponds to steel grade S 690. It is easily visible that for medium values of slenderness $\bar{\lambda}_{z}>0.5$, flexural buckling curves for steel grade S 690 are situated above those for steel grade S 355, for both "geometrically-quasi-perfect" (an infinitesimally small amplitude of $e_{0}=\mathrm{L} / 10000$ ) and "geometrically-most-imperfect" (the tolerance level amplitude of $e_{0}=\mathrm{L} / 750$ ) elements. The following must also be noted from the comparison of results. The bigger value of $\psi_{\mathrm{com}}$ is, the bigger difference between the placement of resistance curves could be seen. Hence, upgrading of buckling curves of welded columns associated with the increase in the steel grade may also be considered. 
This fact is not respected in EN 1993-1-1 [2], which requires for buckling about $z-z$ axis, regardless of the steel grade, to use the curve $c$ for the I-section girders with the flange thickness less or equal to $40 \mathrm{~mm}$ and the curve $d$ otherwise.

\section{CONCLUSIONS}

In paper [1], the approximation of $\xi_{E, \text { eff }}$ and $\psi_{\text {eff }}$ on the basis of $\psi_{c o m}$ was done for steel S 355 . Having in mind that it was proven for high strength steel that parameter $n$ may be assumed to be the same as for steel S 355 without significant loss of accuracy, it would be good to propose similar approximation on $\xi_{E, \text { eff }}$ and $\psi_{\text {eff }}$ parameters for steel grade S 690. The problem is that in case of high strength steels the linear approximation for $\xi_{E, \text { eff }}$ is not valid anymore. On the basis of results presented in Fig. 6, following exponential function $\xi_{E, \text { eff }}\left(\psi_{c o m}\right)=a \operatorname{Exp}\left(b \psi_{c o m}\right)+c$ may be used for approximation.

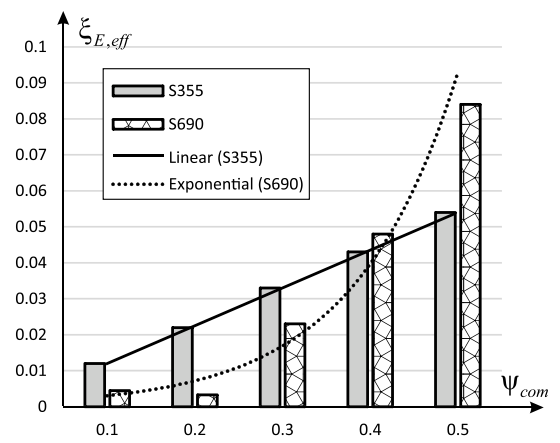

Fig. 6. Approximation of $\xi_{E, e f f}$ parameter for S 690 steel grade versus linear approximation for $\mathrm{S} 355$ grade

Based on the data collected in Table 2 (considering V1 optimization variant) and using Mathematica software, the parameters $a, b$ and $c$ were determined. The outcomes are shown in Table 4 for both steel grades. Presented analyses and its results proved that in case of welded Isection members and high strength steel grades, the degrading effect of residual stresses on the reduction buckling resistance factor of steel compression members is less pronounced that for the common steel grades. The situation is analogous to that of hot rolled beam-columns. 
Table 4. Approximation functions for $\xi_{E, \text { eff }}$ and $\psi_{\text {eff }}$ of BF model for S 355 and S 690 steel grades

\begin{tabular}{|c|c|c|}
\hline Steel grade & $\xi_{E, \text { eff }}$ approx. function & $\psi_{\text {eff }}$ approx. function \\
\hline S 355 & $\xi_{E, e f f}=0.001+0.105 \psi_{\mathrm{com}}$ & $\psi_{\text {eff }}=1.05 \psi_{\mathrm{com}}$ \\
\hline S 690 & $\xi_{E, e f f}=0.0049 \operatorname{Exp}\left(5.83 \psi_{\mathrm{com}}\right)-0.0061$ & $\psi_{e f f}=1.04 \psi_{\mathrm{com}}$ \\
\hline
\end{tabular}

It was also shown that flexural buckling curves for steel grades S 355 and S 690 could be approximated with the same functions of satisfactory accuracy (taking into account the same imperfection parameters $n$ ). Only difference was noticed in case of the $\xi_{E, \text { eff }}$ parameter prediction. The outcomes from executed analyses could be implemented for codification. To draw the above conclusions, it was necessary to perform sensitivity analyses and include the material and geometrical imperfections separately. Performing such analyses, however, requires practice in using FEM tools. It is easier to use equivalent geometrical imperfection approach (according to general method of EN 1993-1-1), but in this case the magnitude of imperfection depends on the adopted buckling curve.

\section{REFERENCES}

1. ABAQUS Theory manual, Version 6.11, Dassault Systèmes (2011)

2. ABAQUS/Standard User's manual, Version 6.11, Dassault Systèmes (2011)

3. M. Giżejowski, M. Gajewski, R. Szczerba, Merchant - Rankine - Murzewski approach for modeling of the buckling resistance of welded I-section colums, MATEC Web of Conferences 262, 09006 (2019)

4. A. Agüero, L. Pallarés, F.J. Pallarés, Equivalent geometric imperfection definition in steel structures sensitive to flexural and/or torsional buckling due to compression, Engineering Structures, 96, 160-177 (2015)

5. A.M. Barszcz, M.A. Giżejowski, A generalized M-R-M approach for modelling of the stability behaviour of imperfect steel elements and structures, Archives of Civil Engineering, LII, 1, 59-86 (2006)

6. F. Bijlaard, M. Feldmann, J. Naumes, G. Sedlacek, The "general method" for assessing the out-of-plane stability of structural members and frames and the comparison with alternative rules in EN 1993 - Eurocode 3 - Part 1-1, Steel Construction 3, No. 1, 19-33 (2010)

7. EN-1993-1-1. Eurocode 3: Design of steel structures Part 1-1: General rules and rules for buildings, Brussels, European Committee for Standardization (2005)

8. B. Launert, R. Szczerba, M. Gajewski, M. Rhode, H. Pasternak, M. Giżejowski, The buckling resistance of welded plate girders taking into account the influence of post-welding imperfections - Part 1: Parameter study, Materials testing 59, No. 1, 47-56 (2017)

9. F. Papp, Buckling assessment of steel members through overall imperfection method. Engineering Structures, 106, 124-136 (2016)

10. R. Szczerba, M. Gajewski, M. Giżejowski, On modelling of the buckling resistance of welded I-section columns, II Baltic Conference for Students and Young Researchers BalCon2018 (2018) [in press]

11. T. Tankova, L. Marques, L. Simões da Silva, A. Andrade, Development of a consistent methodology for the out-of-plane buckling resistance of prismatic beam-columns, Journal of Constructional Steel Research, Vol. $128,839-852$ (2017) 


\section{LIST OF FIGURES AND TABLES:}

Fig. 1. Cross section chosen for analysis, a) geometrical dimensions, b) standard residual stress pattern [1] Rys. 1. Przekrój wybrany do analizy, a) wymiary geometryczne, b) standardowy rozkład naprężeń rezydualnych [1]

Fig. 2. Idealization of I-section properties affected by welding-equivalent stress-strain diagram Rys. 2. Idealizacja właściwości przekroju dwuteowego poddanego spawaniu- ekwiwalentny wykres naprężenie-odkształcenie

Fig. 3. Reduction factors $\chi_{z}$ calculated analytically and from FEM simulations for steel grade S 690, a) $\psi_{\text {com }}=0.1$, b) $\psi_{\text {com }}=0.2$, c) $\psi_{\text {com }}=0.3$, d) $\psi_{\text {com }}=0.4$, e) $\psi_{\text {com }}=0.5$ in case of $e_{0}=\mathrm{L} / 750$ and two different $\mathrm{n}$ values Rys. 3. Współczynniki redukcji $\chi_{z}$ obliczone analitycznie i na podstawie symulacji MES dla gatunku stali $\mathrm{S}$ 690, a) $\psi_{\text {com }}=0.1$, b) $\psi_{\text {com }}=0.2$, c) $\psi_{\text {com }}=0.3$, d) $\psi_{\text {com }}=0.4$, e) $\psi_{\text {com }}=0.5 \mathrm{w}$ przypadku $e_{0}=\mathrm{L} / 750$ i dwóch różne wartości n

Fig. 4. Reduction factors $\chi_{z}$ for welded I-section members depending on $\psi_{\text {com }}$ for: a) S 355 and b) S 690 grade Rys. 4. Współczynniki redukcji $\chi_{z}$ dla spawanych elementów dwuteowych w zależności od $\psi_{\text {com }}$ dla stali: a) S 355 i b) S 690

Fig. 5. Analytically predicted reduction factors $\chi_{z}$ against FEM simulations results for steel grades S 355 and S 690, a) $\psi_{\text {com }}=0.1$, b) $\psi_{\text {com }}=0.2$, c) $\psi_{\text {com }}=0.3$, d) $\psi_{\text {com }}=0.4$, e) $\psi_{\text {com }}=0.5$

Rys. 5. Przewidywane analitycznie współczynniki redukcji $\chi_{z}$ względem wyników symulacji MES dla gatunków stali S 355 i S 690, a) $\psi_{\text {com }}=0,1$, b) $\psi_{c o m}=0,2$, c) $\psi_{\text {com }}=0,3$, d) $\psi_{\text {com }}=0,4$, e) $\psi_{\text {com }}=0,5$

Fig. 6. Approximation of $\xi_{E, e f f}$ parameter for S 690 steel grade versus linear approximation for S 355 grade Rys. 6. Przybliżenie parametru $\xi_{E, e f f}$ dla gatunku stali S 690 w porównaniu z przybliżeniem liniowym dla gatunku S 355

Tab. 1. Buckling curve classification according to EN 1993-1-1

Tab. 1. Krzywe wyboczeniowe według klasyfikacji z EN 1993-1-1

Tab. 2. Parameters describing the equivalent $\sigma-\varepsilon$ BF model for $S 690$ obtained in two step optimization procedure respectively for variant $\mathrm{V} 1$ and $\mathrm{V} 2$

Tab. 2. Parametry opisujące równoważną zależność $\sigma-\varepsilon$ modelu BF dla S 690 uzyskany w dwuetapowej procedurze optymalizacji odpowiednio dla wariantu V1 i V2

Tab. 3. Parameter n obtained for S 690 grade using two V1 and V2 variants for $e_{0}=\mathrm{L} / 10000$ and $e_{0}=\mathrm{L} / 750$ Tab. 3. Parametr n uzyskany dla stali S 690 przy użyciu dwóch wariantów optymalizacji V1 i V2 dla $e_{0}=$ $\mathrm{L} / 10000$ i $e_{0}=\mathrm{L} / 750$

Tab. 4. Approximation functions for $\xi_{E, \text { eff }}$ and $\psi_{\text {eff }}$ of BF model for S 355 and S 690 steel grades

Tab. 4. Funkcje aproksymacyjne dla $\xi_{E, \text { eff }}$ i $\psi_{\text {eff }}$ modelu BF dla gatunków stali S 355 i S 690 


\section{PODEJŚCIE Z WYKORZYSTANIEM WARTOŚCI MINIMALNYCH PRZY MODELOWANIU NOŚNOŚCI NA WYBOCZENIE SPAWANYCH SŁUPÓW DWUTEOWYCH ZE STALI O WYSOKIEJ WYTRZYMALOŚCI}

Słowa kluczowe: krzywa wyboczeniowa, spawane słupy dwuteowe, stal o wysokiej wytrzymałości, modelowanie MES

\section{STRESZCZENIE:}

Współczesne normy projektowania konstrukcji stalowych wyróżniają dwa obszary zastosowania stali w budownictwie. W budownictwie powszechnym, w szczególności odnoszącym się do budynków o stalowej konstrukcji szkieletowej, stosowane są stale zwykłe oraz stopowe o podwyższonej wytrzymałości (kategoria wytrzymałościowa od S 235 do S 460). W stalowym budownictwie specjalnym, gdzie wymagana jest wyższa niezawodność konstrukcji stalowych, stosowane są stale o wysokiej wytrzymałości, najczęściej o kategorii wytrzymałościowej S 690. W pierwszym z wymienionych wyżej obszarów zastosowania stali konstrukcyjnej, stosuje się odmienne zasady klasyfikacji krzywych wyboczeniowych do wyznaczania nośności słupów z kształtowników walcowanych oraz spawanych [7]. W wypadku kształtowników walcowanych ze stali kategorii wytrzymałościowej równej i wyższej niż S 460 postuluje się „podwyższenie” krzywej wyboczeniowej w stosunku do krzywej obowiązującej dla wyrobów ze stali o kategorii wytrzymałościowej niższej niż S 460. W odniesieniu do wyrobów spawanych ze stali o katerorri wytrzymałościowe S 460 oraz wyżej, nie przewiduje się „podwyższenia” krzywej wyboczeniowej. W niniejszym artykule podjęto próbę analitycznego sformułowania krzywych wyboczeniowych spawanych słupów stalowych o bisymetrycznym przekroju dwuteowym ze stali S 690 oraz dokonano porównania wyników z otrzymanymi dla analogicznych słupów spawanych ze stali o kategorii wytrzymałościowej niższej niż S 460 .

Celem artykułu jest wyznaczenie krzywych wyboczeniowych w przypadku spawanych elementów ściskanych wykonanych ze stali S 690. Rozważane zagadnienie stanowi kontynuację pracy [3], gdzie analogiczne zagadnienie rozważano dla stali S 355. Zastosowano, zweryfikowane w [3] jako najbardziej wiarygodne, podejście analityczne Best Fit z uwzględnieniem metody randomizacji Merchanta-Rankine’a-Murzewskiego. Kalibrację sformułowania analitycznego przeprowadzono na podstawie wyników symulacji MES z programu ABAQUS. Wyniki obliczeń numerycznych posłużyły do wyznaczenia parametrów materiałowych zaproponowanego modelu analitycznego. Wyznaczenie parametrów materiałowych było możliwe dzięki zastosowaniu metod optymalizacji nieliniowej i pakietu Wolfram Mathematica. Elementy ściskane modelowano w MES stosując teorię powłok dużych deformacji oraz modele konstytutywne sprężysto-plastyczności ze wzmocnieniem izotropowym. Naprężenia pospawalnicze modelowano poprzez wstępne samozrównowazone pole naprężeń rezydualnych. Pole naprężeń rezydualnych określone było przez dwa parametry: $\psi_{t e n} \mathrm{i} \psi_{c o m}$ odpowiednio dla strefy rozciąganej i strefy ściskanej. Parametr naprężenia rezydualnego $\psi_{t e n}$ jest utrzymywany na stałym poziomie dla różnych historii wymiany ciepła przy spawaniu. W konsekwencji tylko $\psi_{\text {com }}$ jest dalej uważany za zmienną. W analizie przyjęto wartości dyskretne z zakresu od 0.1 do 0.5 , uwzględniając różne historie obciążenia termicznego wynikającego z przebiegu procesu spawania.

Ściskanie elementu przegubowo podpartego na obu końcach realizowano poprzez zadanie przemieszczeniowych warunków brzegowych w odpowiednich węzłach odniesienia na końcach elementu. Wstępne ekwiwalentne imperfekcje geometryczne zadawano zgodnie $\mathrm{z}$ wymaganiami normowymi przyjmując dwa skrajne przypadki, tj. $e_{0}=\mathrm{L} / 10000$ i $e_{0}=\mathrm{L} / 750$ dla prętów o różnej długości (w przedziale smukłości względnej od około 0.5 do 1.5 ). W pierwszym przypadku mamy do czynienia z elementem niemal ,idealnym”, podczas gdy w drugim przypadku wartość mnożnika 
imperfekcji należy uznać za znaczną. Szczegółowo przyjęty do symulacji model MES przedstawiono w [8]. W pracy zweryfikowano zaproponowany model analityczny dla stali wysokiej wytrzymałości S 690. Przewidywania tego modelu porównano z wynikami uzyskanymi w pracy [3] w przypadku stali S 355 oraz rozszerzono jego zastosowanie dla stali S 690. Wykazano, że współczynnik imperfekcji $n$ można przyjmować niezależnie od gatunku stali odpowiednio dla $e_{0}=L / 10000$ jako równy 6.0 zaś dla $e_{0}=L / 750$ jako równy 1.6 . Pozostałe parametry modelu tj. $\xi_{E, e f f}$ i $\psi_{\text {eff }}$ można aproksymować względem zmiennej $\psi_{\text {com }}$ odpowiednio funkcjami liniowymi w przypadku S 355 i ekspotencjalnymi w przypadku S 690. Oznacza to, że wszystkie przypadki pośrednie mogą być aproksymowane na podstawie wyznaczonych funkcji aproksymacyjnych w zależności od wielkości wstępnej imperfekcji oraz parametru charakteryzującego rozkład naprężeń rezydualnych $\psi_{\text {com }}$.

Przedstawione wyniki analiz wskazują, że w wypadku słupów spawanych, wykonanych ze stali o wysokiej wytrzymałości, występuje efekt podwyższenia wartości współczynnika wyboczeniowego w odniesieniu do wyznaczanego na podstawie krzywej wyboczeniowej wyznaczonej dla stali zwykłych i stopowych o podwyższonej wytrzymałości. Podjęcie szerszych badań symulacyjnych pozwoli na uszczegółowienie wniosków do wykorzystania w normalizacji projektowania spawanych konstrukcji stalowych ze stali o kategorii wytrzymałościowej S 460 oraz wyższej.

Received 07.09.2019

Revised 19.10.2019 